
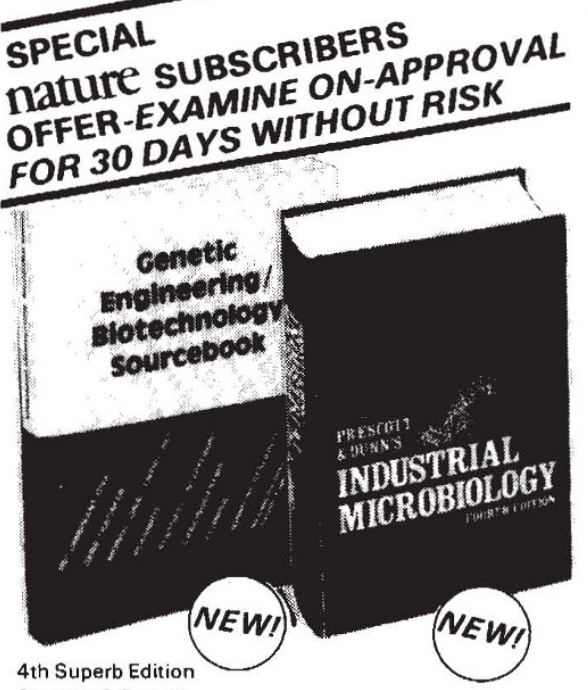

Prescott \& Dunn?

Industrial Microbiology

Edited by Gerald Reed

Vice President. Amber Laboratories USA

The up-to-date guide and reference tool to industrial technology and applications in the microbiology of foods and food ingredients - with a special section on biological production of fuel alcohol.

Macmitlan Hardcover $896 \mathrm{pp} \quad \mathbf{f} 42.50$
ISBN $0333336305 \quad 1982$

\section{Genetic Engineering/}

\section{Biotechnology Sourcebook}

Never before published Profiles of 1,529 recent and ongoing genetic engineering/biotechnology research projects funded by 122 US government and non-profit organizations.

Covers research affecting: $\star$ Pharmaceuticals $\star$ Medicine and Diagnosis $\star$ Agriculture $\star$ Food Processing $\star$ Energy $\star$ Chemicals.

Reveals for each project $\square$ Nature and objectives of research Funding source and money awarded

Special Yellow Pages reference section - telis you at Special Yellow Pages reference section - tells you at a . Macmillan Softcover 350 pp $\quad £ 52.50$ ISBN 03333414811982

Place your on-approval order today!

\section{GLOBE \\ BOOK SERVICES LTU}

Canada Road, Byfleet, Surrey KT 14 7JL, England. Tel: Byfleet (09323) 40397

A MEMBER COMPANY OF MACMLLAN PUBUSHERS LTD.

\section{EXAMINE ON 30 DAYS}

\section{APPROVAL}

To: Ian Jacobs, Globe Book Services Ltd., FREEPOST Canada Road, Byfleet, Surrey KT14 7BR. England. (Please tick books required)

Please send me- copies of $\square$ Genetic Engineering/Biotechnology Sourcebook at $\mathbf{5 5 2 . 5 0}$ each plus P\&P (UK $f 2$. Overseas $\varepsilon 3$.) and/o

copies plus P\&P (UK $f 2$. Overseas $f 3$ ) on 30 days approval. If am not completelysatisfied.I mayreturn the volume(s)

Tick preferred method of payment

$\square$ I enclose cheque for $f$

$\square$ Charge my credit card $f$

$\square$ Visa $\square$ Access $\square$ American Express $\square$ Diners

Card No.

$\square$ Bill me. I need send no money now.

Signature

Orders cannot be accepted without a signature

Name

Address

(PLEASE PRINT)

\title{
What price a physiological wonder?
}

\section{John Rivers}

Vitamin C. The Mysterious Redox-System - A Trigger of Life? By Silvia Nobile and Joan Mary Woodhill. Pp.185. ISBN 0-85200-419-2. (MTP Press: 1982.) £11.95, $\$ 29$. Vitamin $C$ in Health and Disease. By T. K. Basu and C. J. Schorah. Pp.152. UK ISBN 0-07099-0445-2; US ISBN 0-87055-406-9. (Croom Helm/Avi: 1982.) £11.95, \$19.50. Vitamin C (Ascorbic Acid). Edited by J. N. Counsell and D. H. Hornig. Pp.383. ISBN 0-85334-109-5. (Applied Science: 1982.) £32.

FASCINATING stuff vitamin C: it makes you ill if you don't eat it. And if you believe what you read in these books it cures almost every affliction known to man: not just scurvy, but colds, cancer and cardiovascular disease. It also apparently needs talking about over and over again, which is why there are three recent books to review instead of just one.

Three new books might seem three too many. After all vitamin $C$ is already a bit of a nutritional cliché. The dietary sources are so well known even nutritionists don't need to look them up. The assay for it is so simple, it is part of almost all nutrition courses - even school-children are taught to measure vitamin $\mathrm{C}$ (and consequently discover just how little there is in their overcooked school lunches) and the deficiency disease has been controllable for nearly two centuries. Since, in fact, James Lind's famous experiments with the British Navy which provided a steady market for West Indian limes and an apparently indestructible nickname for the English.

The real justification for these books is the notion that old hat and practically unimportant as the antiscorbutic properties of vitamin $\mathrm{C}$ may be, it also has a different incarnation, one of importance to us all since it means this vitamin though chemically only a simple carbohydrate, is a physiological wonder, the key to many of the uncured ills of our age.

Superficially the books seem very different; Counsell and Hornig are the editors of a symposium, Basu and Schorah are authors of an undergraduate textbook, and Nobile and Woodhill ... well, what can be said about a book whose subtitle is The Mysterious Redox-System - A Trigger of Life?

Anyone buying the book to find out about life's trigger will be disappointed. It is mysterious because it doesn't actually appear in the text, and vitamin $\mathrm{C}$ as an in vivo redox system is only dealt with briefly and obscurely. However, most of the book provides a competent introduction to this most over-discussed vitamin, although unfortunately the authors don't seem quite sure who they are writing for. I found that their literary style lacked consistency and was in places convoluted, elsewhere reminiscent of Enid Blyton.
Basu and Schorah are presumably competing for the same book market, though they do so by producing a more terse and more conventionally "scientific" monograph. What spoils it for me is that their enthusiasm and commitment to the importance of vitamin $\mathrm{C}$ in human health results in a somewhat atrophied critical faculty. For example, they reproduce on page 96 a graph, ascribed to Ginter, which, they argue, shows that in guinea pigs the rate of transformation of cholesterol to bile acids is related to hepatic vitamin C concentration. Actually it shows that in one group of vitamin $\mathrm{C}$ deficient guinea pigs with hepatic vitamin $C$ concentrations in the range $0-4 \mathrm{mg} / 100 \mathrm{~g}$, the rate of transformation ranged from 5 to $12 \mathrm{mg} / \mathrm{day} / 500 \mathrm{~g}$ liver, while in another group of normal guinea pigs where the concentration ranged from 5 to 12 , the rate of transformation ranged from 8 to 16 . To my eye within neither group was any correlation evident, nor was the difference between the groups statistically significant. To Basu and Schorah it is the illustration of a proven fact, and the beginning of a section which ends by proposing that changes in vitamin $\mathrm{C}$ status are central in fluctuations in mortality from ischaemic heart disease.

My reservations about the last book in the trilogy, entitled simply Vitamin $C$ (Ascorbic Acid), are of a different kind. The book is solid science (apart from the reappearance of Ginter's graph) and covers food science and analytical chemistry, as well as nutrition in a competent, plodding manner. But it has arisen out of a symposium organized and sponsored by Roche Products Limited and its editors work for the Roche empire, as do 5 of its 24 distinguished contributors who report on, inter alia, the prevalence of subclinical vitamin $\mathrm{C}$ deficiency and the safety of megavitamin $\mathrm{C}$ dosage.

This kind of commercial intertwining is inevitable in modern science but I wish that the book simply pointed out that Roche market vitamin C. And I wish that the book included a chapter on the boom that there has been in vitamin C self-supplementation as book after article after broadcast has advocated megavitamin therapy.

All the enthusiasm for vitamin $\mathrm{C}$ arises because human beings need it, and a major end product of all this scientific activity is persuading ordinary people that they need to take supplements of the stuff. A daily gram tablet of Redoxon in my local chemists costs over 7 pence and it sells well. I don't say that all discussions should start there, but I do think they should mention it.

John Rivers is a Lecturer in the Department of Human Nutrition at the London School of Hygiene and Tropical Medicine. 